\title{
Parental divorce and parental death - An integrative systematic review of children's double bereavement
}

\author{
Jette Marcussen ${ }^{* 1,2}$, Frode Thuen ${ }^{3,4}$, Poul Bruun², Lise Hounsgaard ${ }^{2,5}$ \\ ${ }^{1}$ Department of Nursing, University College Lillebaelt, Odense, Denmark \\ ${ }^{2}$ Health Sciences Research Center, University College Lillebaelt, Denmark \\ ${ }^{3}$ Bergen University College, Bergen, Norway \\ ${ }^{4}$ Centre for Family Development, Copenhagen, Denmark \\ ${ }^{5}$ OPEN, Institute of Clinical Research, University of Southern Denmark, Odense, Denmark
}

Received: May 18, 2015

DOI: $10.5430 / \mathrm{cns} . v 3 n 4 p 103$
Accepted: September 1, $2015 \quad$ Online Published: September 21, 2015

URL: http://dx.doi.org/10.5430/cns.v3n4p103

\begin{abstract}
The aim of this review was to identify research on children and adolescents who experience double bereavement, i.e. the experience of loss through parental divorce followed by either parental death or critical illness with imminent death. This knowledge may identify evidence to underpin knowledge and practice for nurses and other health professionals, so they can intervene with these children and adolescents more efficaciously. An integrative systematic review was conducted using PubMed, CINAHL and PsycINFO. The results show four major themes: Complexity in their experiences of double bereavement; challenges in both custodial and non-custodial parental death; risk of mental health problems, and the need of support and interventions.
\end{abstract}

Key Words: Adolescent, Bereavement, Child, Divorce, Critical illness, Parental death

\section{INTRODUCTION}

This article presents an integrative, systematic literature review ${ }^{[1]}$ of research on children and adolescents who experience double bereavement. ${ }^{[2]}$ In this article, we use the term "double bereavement" to refer specifically to the double loss experienced as a consequence of parental divorce in combination with the subsequent death of a parent or development of a parent's critical illness where death is imminent or expected. Children and adolescents in this situation experience loss upon loss.

High divorce rates - in most European countries these are more than $40 \%,{ }^{[3]}$ would indicate that many children and adolescents experience double bereavement. According to registration data from Statistics Denmark, a total of 12,707 children under 18 years had lost one or both of their parents by January 2015. Among these children, 3,691 had previously experienced a parental divorce. Thus, $36.9 \%$ of all children who have lost a parent, have also experienced a parental divorce earlier in life. ${ }^{[4]}$ These figures correspond well with estimates from USA, suggesting that around 50\% of children who have experienced parental death, have experienced parental divorce earlier in life. ${ }^{[5,6]}$ Thus, a substantial proportion of children and adolescents who experience parental death or a critically ill parent may also have a former experience of parental divorce.

Because of the challenges children and adolescents encounter in their loss and double bereavement, they may have elevated

\footnotetext{
*Correspondence: Jette Marcussen; Email: jema4@ucl.dk; Address: Department of Nursing, University College Lillebaelt, Roedtjoernvej 48, 5200 Odense V, Denmark.
} 
risk of developing mental health problems. ${ }^{[7,8]}$ Although the consequences for children and adolescents experiencing one of the losses have been explored, ${ }^{[7,9-11]}$ there is scant research on how children and adolescents experience double bereavement, and the kind of psychosocial support or interventions they may need.

A number of studies from various countries indicate that children from divorced families have lower levels of well-being and self-esteem, and lower levels of education and higher dropout rates from school, as compared to children growing up with both their parents. ${ }^{[9,10]}$ They also smoke more, start drinking alcohol at an earlier age, show higher rates of criminality, have earlier sexual debuts, enter motherhood younger, and experience a higher risk of divorce. ${ }^{[10,12]}$ Detrimental effects of parental divorce on the offspring's psychosocial development are seen irrespective of time since the divorce, ${ }^{[13]}$ and may last into adulthood. ${ }^{[14,15]}$ In some studies, long term effects has been observed, where the consequences appear only after several years. ${ }^{[16]}$

Furthermore, research on children of parents with cancer indicates that poor prognosis and advanced illness are related to worse adjustment in children. ${ }^{[7,17]}$ The child's premorbid mental health conditions and level of preparedness for the death could moderate any post-death psychological problems, such as complicated grief, anxiety and depression. ${ }^{[11]}$ More generally, studies have shown poorer quality of life and particularly higher prevalence of depression among bereaved children and adolescents, ${ }^{[11,18]}$ as compared to young people without any bereavement experiences. ${ }^{[7]}$

A few studies have compared children or adolescents who have experienced either parental divorce or parental death, with mixed results. Some studies failed to find significant differences between divorce and parental death outcomes, ${ }^{[19,20]}$ whereas other studies indicated more negative outcomes after parental divorce than parental death, ${ }^{[18,21]}$ and still other studies indicated worse effects of experiencing the loss of a parent. ${ }^{[22]}$

\section{Aim and research question}

The aim of this review was to identify and describe research on children and adolescents' who have experienced double bereavement, in order to enable nurses and health professionals to understand, support and intervene with these children and adolescents as efficaciously as possible. The review will search for an answer to the following question: How does the child or adolescent express their experiences of double bereavement and its consequences, when faced with the challenges posed in the dual losses involved in parental divorce and parental death or critical illness with expected death?

\section{METHODS}

The systematic, integrative literature review investigated peerreviewed research. We were inspired by Whittemore and Knafl's strategy for conducting an integrative review, evaluating and analyzing the data, and qualifying the synthesis of the results. ${ }^{[1]}$ The review used the matrix method, which follows a structured approach and process. ${ }^{[23]}$

\subsection{Search strategy}

The international databases PubMed, CINAHL and PsycINFO were searched. The search strategy was developed through basic searches, checking for MeSH-terms and headings and keywords, combined with thesaurus. Finally, only sources with the terms ([bereavement or grief or mourning] AND [children or adolescent] AND [neoplasms or cancer] or [critical illness] or [death or parental death]) and (divorce or parental divorce) were included in the study. The terms for the final search were adapted into each database, as seen in Table 1, which shows the search terms from PubMed. In CINAHL and PsycINFO, the terms were adapted to the terms in the databases. It can be seen in the flowchart in Figure 1 how the research was found and chosen. This ensured transparency in the review process, consistency with the stated aim and replicability of the research. ${ }^{[1]}$

Table 1. Search terms used in PubMed

\begin{tabular}{|c|c|c|c|}
\hline Facet 1 & Facet 2 & Facet 3 & Facet 4 \\
\hline TA Child $^{*}$ & AF Bereavement ${ }^{*}$ & TA Cancer* & Divorc $^{*}$ \\
\hline Or & Or & Or & \\
\hline TA Adolescent ${ }^{*}$ & AF/MeSH Bereavement & TA Neoplasm* & \\
\hline Or & Or & Or & \\
\hline MeSH Child & AF Grief* & TA/MeSH Parental death & \\
\hline Or & Or & Or & \\
\hline \multirow[t]{3}{*}{ MeSH Adolescent } & AF/MeSH Mourning & TA/MeSH Critical illness & \\
\hline & Or & Or & \\
\hline & AF Mourning* & TA/MeSH Death & \\
\hline
\end{tabular}

*Thesaurus, $\mathrm{TA}=($ Title/Abstract $) ; \mathrm{AF}=($ All Fields $) \mathrm{MeSH}$ 


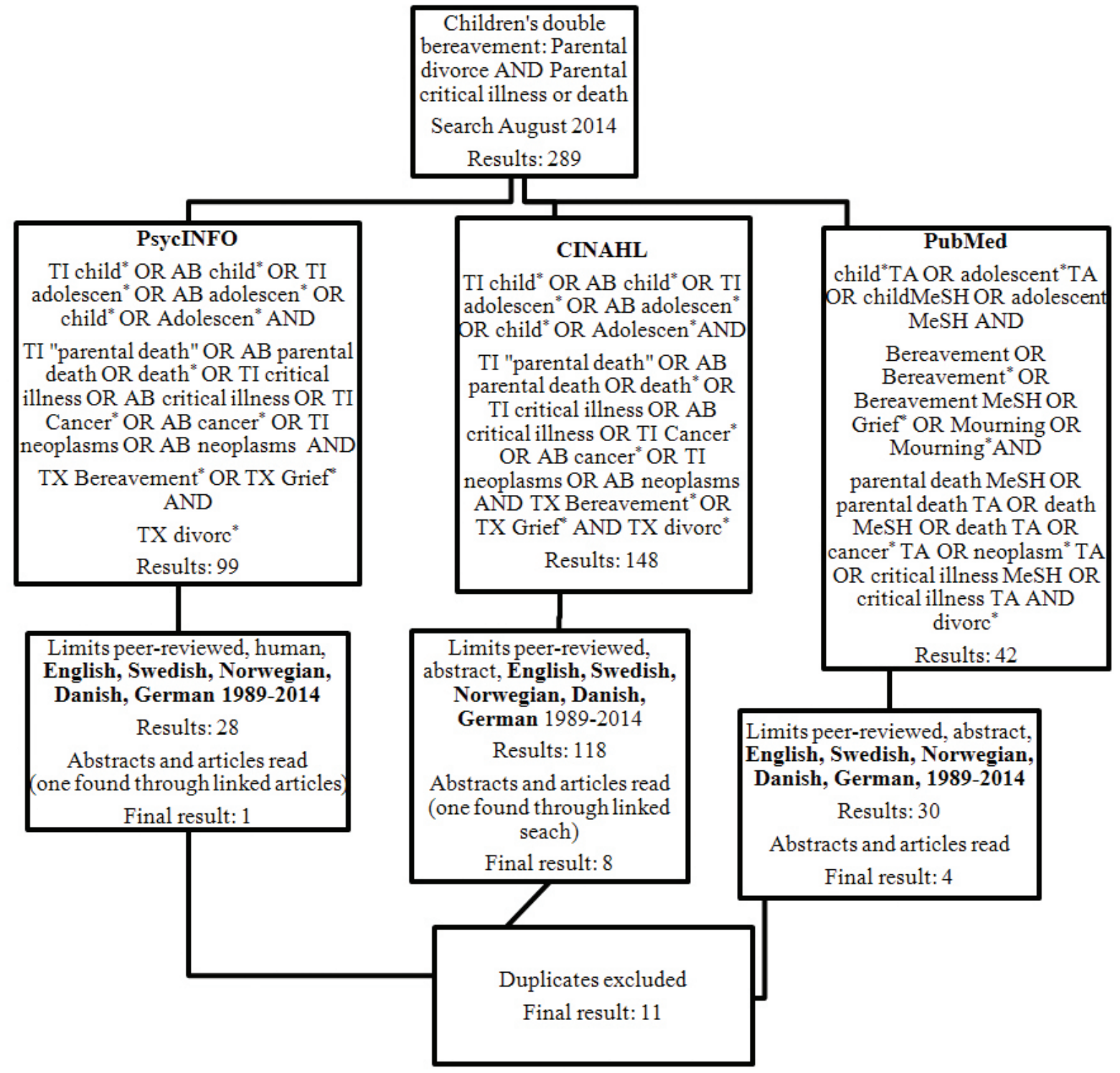

Figure 1. Flowchart

\subsection{Inclusion criteria}

(1) Empirical studies using and systematically describing their qualitative or/and quantitative research method

(2) Research published 1989-2014

(3) Peer-reviewed and with abstract

(4) Languages: English, German, Swedish, Norwegian or Danish

(5) Studies covering the double perspective for children and adolescents of divorce and critical illness or death

\subsection{Exclusion criteria}

(1) Research only covering similarities between divorce or critical illness or death

(2) Parental death in catastrophic events
(3) Overviews, editorials, comments, theoretical manuscripts

(4) Non-peer-reviewed research

\subsection{The analysis process}

The analysis process is described by Whittemore and Knaf ${ }^{[1]}$ (see Figure 1). First, titles and abstracts were read and initial selections were made. Articles and dissertations were included if they covered divorce and critical illness or death. Then, full articles and dissertations were read and the next selection and reduction were made.

The included papers were abstracted carefully. Data display is shown in the review matrix (see Table 2)..$^{[1,23]}$ The included articles cover expressions of the double loss and be- 
reavement of children and adolescents due to parental divorce coupled with either parental critical illness with risk of death, or parental death. The data comparison involved counting the data, finding themes and data relation. In the discussion and conclusion of the data, the data comparison also included, as described by Whittemore and Knaf ${ }^{[1]}$ and inspired by Miles and Huberman: Subsuming particulars into general, noting relations between variability, finding intervening factors and building the logical chain of evidence. ${ }^{[1,24]}$ This was done through discussion of the themes and subcategories. Syntheses of the research were made, after the final sample was qualified through the quality criteria and data related. When data were conceptualized to a higher level of abstraction, the primary source was reviewed to verify the synthesis. ${ }^{[1]}$

Table 2. Literature review matrix

\begin{tabular}{|c|c|c|c|c|}
\hline & Sample & Method & Results & $\begin{array}{l}\text { Qualification } \\
\text { high or low }\end{array}$ \\
\hline Morgan C, et al. ${ }^{27}$ & $\begin{array}{l}\mathrm{N}=390 \text { age } 16-64 \text { Separation or/and loss } \\
\text { by death before age } 16 \text { and by first episode } \\
\text { of psychosis; } n=391 \text { community control }\end{array}$ & $\begin{array}{l}\text { Quantitative } \\
\text { case control }\end{array}$ & $\begin{array}{l}\text { Experience of long-term separation/divorce and parental death before } \\
\text { the age of } 16 \text { gave two to threefold increased risk of psychosis } \\
\text { compared to controls }\end{array}$ & $\begin{array}{l}\text { 1: High } \\
\text { 2: Low }\end{array}$ \\
\hline Oakley Browne, et al. ${ }^{28}$ & $\begin{array}{l}\mathrm{N}=777 \text { women aged } 18-44 \text { with } \\
\text { disruptions in childhood care because of } \\
\text { prolonged separation before age } 15\end{array}$ & $\begin{array}{l}\text { Quantitative } \\
\text { survey }\end{array}$ & $\begin{array}{l}\text { Prolonged separation (illness or death and separation) < age } 15 \text { from } \\
\text { both parents increased the risk } 3-4 \text { times for current or lifetime } \\
\text { depression in women aged 18-44 than did one of: parental death or } \\
\text { divorce or other loss }\end{array}$ & $\begin{array}{l}\text { 1: High } \\
\text { 2: Low }\end{array}$ \\
\hline Grossman, et al. ${ }^{29}$ & $\begin{array}{l}\mathrm{N}=16 \text { children age } 6-12 \text { and mothers and } \\
\text { an adult relative or caretaker. Within } 25 \\
\text { months of paternal suicide }\end{array}$ & $\begin{array}{l}\text { Quantitative } \\
\text { interview }\end{array}$ & $\begin{array}{l}\text { Post-Traumatic Stress Disorder (PTSD) significant related to parental } \\
\text { threats of divorce and death. } p<.02 \text { for Reaction Index score and } \\
\text { exposure to divorce. Grief and trauma as separate and overlapping } \\
\text { phenomena are supported. Reminiscing most frequent grief } \\
\text { behaviour. Supportive mothers and support groups facilitate coping }\end{array}$ & $\begin{array}{l}\text { 1: High } \\
\text { 2: Low }\end{array}$ \\
\hline Bugge, et al. ${ }^{26}$ & $\begin{array}{l}\mathrm{N}=13 \text { parents }(n=6) \text { patients with cancer } \\
(n=3 \text { divorced) and partners and } \\
\text { ex-partner }(n=7) . \mathrm{N}=12 \text { children age } \\
\text { 5-18. All attending Family Support } \\
\text { Programme }\end{array}$ & $\begin{array}{l}\text { Qualitative } \\
\text { in-depth } \\
\text { interview }\end{array}$ & $\begin{array}{l}\text { Divorced families were helped by: Talking with children, dealing } \\
\text { with difficult questions and tasks, identifying resources } \\
\text { inside/outside the family, planning the future. Parents learned to } \\
\text { support their children during parent's terminal illness. Conflicts } \\
\text { reduced. }\end{array}$ & $\begin{array}{l}\text { 1: High } \\
\text { 2: Low }\end{array}$ \\
\hline Bugge, et al. ${ }^{25}$ & $\begin{array}{l}\mathrm{N}=6 \text { families, } n=12 \text { children aged } 6-16 . \\
\mathrm{N}=5 \text { children with parental divorce. } \\
\text { Family Support Programme }\end{array}$ & $\begin{array}{l}\text { Qualitative } \\
\text { in-depth } \\
\text { interview }\end{array}$ & $\begin{array}{l}\text { Children need to talk without having to think about other family } \\
\text { members' reactions. } \\
\text { They also need to be in dialogue with other family members. }\end{array}$ & $\begin{array}{l}\text { 1: High } \\
\text { 2: Low }\end{array}$ \\
\hline Gordon, et al..$^{30}$ & $\begin{array}{l}\text { Custody case of } n=1 \text { mother with } 2 \text { sons } \\
\text { described by } 5 \text { professionals }\end{array}$ & $\begin{array}{l}\text { Qualitative } \\
\text { case study }\end{array}$ & $\begin{array}{l}\text { Problems with conflict and custody have great impact on children } \\
\text { when their parent is dying. Conflict between divorced parents needs } \\
\text { involvement from nurse/other professionals. Family group sessions } \\
\text { can be helpful. Important to help parents make rational, legal } \\
\text { decisions for the sake of the children. When a non-custodial parent } \\
\text { has been absent, it is still relevant to consider if children want a } \\
\text { relationship. }\end{array}$ & $\begin{array}{l}\text { 1: Low } \\
\text { 2: High }\end{array}$ \\
\hline Davey, et al. ${ }^{31}$ & $\begin{array}{l}\mathrm{N}=6 \text { families, } n=6 \text { parents with cancer } \\
\text { diagnosed within last } 4 \text { years ( } 4 \text { divorced, } \\
1 \text { remarried, } 1 \text { married) } n=2 \text { spouses } n= \\
10 \text { adolescent children aged } 11-18\end{array}$ & $\begin{array}{l}\text { Qualitative } \\
\text { retrospective } \\
\text { multiple case } \\
\text { pilot study }\end{array}$ & $\begin{array}{l}\text { Themes: Worry and fear, protection, adjustment, coping, support. } \\
\text { The adolescent in the divorced family protects parents by not sharing } \\
\text { feelings. Parents often unaware of the stress and overwhelming } \\
\text { feelings of sadness and fear in their adolescent. Single/divorced } \\
\text { mothers are more worried for their children. }\end{array}$ & $\begin{array}{l}\text { 1: Low } \\
\text { 2: Low }\end{array}$ \\
\hline $\mathrm{Lu}$, et al. ${ }^{32}$ & $\begin{array}{l}254 \text { adults with severe mood disorders } \\
\text { (SMD) correlates to adverse childhood } \\
\text { experiences }\end{array}$ & $\begin{array}{l}\text { Quantitative } \\
\text { Retro-spective } \\
\text { survey }\end{array}$ & $\begin{array}{l}\text { Of 91adults that had experienced parental separation or divorce, } 10 \% \\
\text { experienced parental death < age } 16 \text {. Of } 25 \text { adults with parental death, } \\
36 \% \text { had experienced parental separation or divorce }\end{array}$ & $\begin{array}{l}\text { 1: Low } \\
\text { 2: Low }\end{array}$ \\
\hline Werner-Lin, et al. ${ }^{6}$ & $\begin{array}{l}\mathrm{N}=1 \text { female (age } 13) \\
\mathrm{N}=1 \text { male (age } 12)\end{array}$ & $\begin{array}{l}\text { Qualitative case } \\
\text { study }\end{array}$ & $\begin{array}{l}\text { Custodial parental death may separate children from step or } \\
\text { half-siblings. Young children need reconstructed stories. Children } \\
\text { fantasize about being reunited with non-custodial parent. } \\
\text { Transition to new homes and new family culture means loss of place, } \\
\text { relatives and lifestyle, loss of attachment to lost parent. Children with } \\
\text { parental critical illness wonder who will take them, and they } \\
\text { experience loneliness and depression. Therapeutic relationship helps } \\
\text { child during transition. }\end{array}$ & $\begin{array}{l}\text { 1: Low } \\
\text { 2: High }\end{array}$ \\
\hline Walls $^{33}$ & $\begin{array}{l}\mathrm{N}=103 \text { psychology students rating } \\
\text { expected support to child grief to paternal } \\
\text { loss in divorced/intact families eight } \\
\text { scenarios about females and death of } \\
\text { biological father. Three variables: } 1 \text {. } \\
\text { Family structure (intact/divorced); } 2 \text {. } \\
\text { Father relationship (close, involved/ } \\
\text { distant, uninvolved); } 3 \text {. Surviving mother } \\
\text { (close, supportive/ distant, } \\
\text { non-supportive) }\end{array}$ & $\begin{array}{l}\text { Quantitative } \\
\text { question-naire }\end{array}$ & $\begin{array}{l}\text { Family structure (intact or divorced) impacts the grief reactions when } \\
\text { parent uninvolved. When father is uninvolved or failed close } \\
\text { relationship, the impacts were only found when divorced and the } \\
\text { grief was disenfranchised and then the expectations of death-related } \\
\text { rituals were also viewed as being less appropriate. Disenfranchised } \\
\text { grief is seen significantly in response to non-custodial death. } \\
\text { From supporters the grief responses, symptoms, support, expressions } \\
\text { of sympathy are less expected to occur in loss of the non-custodial } \\
\text { father. When surviving mothers are supportive (as opposed to } \\
\text { non-supportive), the expected support the griever gets is significantly } \\
\text { better ( } p<.001)\end{array}$ & $\begin{array}{l}\text { 1: High } \\
\text { 2: High }\end{array}$ \\
\hline Walls $^{34}$ & $\begin{array}{l}\mathrm{N}=10 \text { aged } 18-41 \text {, aged } 5-20 \text { when } \\
\text { separated from parent; aged } 10-30 \text { when } \\
\text { non-custodial parent died }\end{array}$ & $\begin{array}{l}\text { Qualitative } \\
\text { interview }\end{array}$ & $\begin{array}{l}\text { Grief reaction to non-custodial death: Lack of closeness meant that } \\
\text { the sense of loss was low, but shown through feelings as apathy, } \\
\text { anger/resentment and relief; } 1 \text { boy who lost his mother did not } \\
\text { remember feeling anything, } 3 \text { did not attend funeral. People still } \\
\text { expected them to grieve. Pre-loss relationship: Disenfranchised grief } \\
\text { results in confusion, anger, guilt, shame and sorrow. Anger differs } \\
\text { from normal grief reaction; by not felt understood, being denied right } \\
\text { to openly grieve, denied funeral, and self-anger. Relationship with } \\
\text { surviving parent: Normal grief reactions as in intact families: Shock, } \\
\text { numbness, disbelief, intense mourning and period of adjustment. } \\
\text { Reactions of others to the loss and grief experience: Disenfranchised } \\
\text { grievers are left unsupported. Disenfranchised grief symptom: } \\
\text { Lasting difficulties in dealing with death. }\end{array}$ & $\begin{array}{l}\text { 1: High } \\
\text { 2: High }\end{array}$ \\
\hline
\end{tabular}




\subsection{Quality criteria}

The articles comprising the final sample were assessed with regard to methodological scientific standards and relevance to the present research, and dichotomized into either a high or low category as described by Whittemore and Knarf. ${ }^{[11]}$ Regarding relevance, articles with clear research results on the double loss and bereavement were rated high, and rated low if the results were less relevant or had other variables that could confuse or not relevant to the study, such as adverse childhood experiences like abuse. For methodological/theoretical rating, the scientific standard for both qualitative and quantitative research is followed. None of the articles were excluded in this process. ${ }^{[1,23]}$

\section{RESUlTS}

As depicted in the flowchart in Figure 1, a total of 289 articles were found in the literature review. In the process of elimination, 176 remained. The abstracts and articles were read, and studies that fulfilled our criteria were included. The reference lists of these articles were checked for any other relevant studies, resulting in one more study by Bugge, Helseth and Darbyshire. ${ }^{[25,26]}$ Eleven studies published from 1995 to 2009 , and conducted in the USA $(n=7)$; UK $(n=1)$; Australia $(n=1)$ and Norway $(n=2)$ were finally included in the current integrative review. Six of the studies used a qualitative approach, whereas the other five studies were based on quantitative methods. Seven studies were rated as high and four as low in terms of methodology/theoretical rigour, whereas four studies were rated as high and seven as low regarding relevance. ${ }^{[1]}$

Four studies in the review, as set out in Table 2, were scored as highly relevant for this study. ${ }^{[6,30,33,34]}$ Werner- Lin et al. found that, when children of divorced parents have a custodial critically ill parent, they experience loneliness, depression and worry about who will take care of them when their parents die. When their custodial parent dies, they experience multiple losses, such as loss of lifestyle, home, relatives and friends. The loss of the house symbolizes loss of attachment to the lost parent, and the transition to a new home and a new custodial adult or parent leaves the child with stress. ${ }^{[6]}$ The child may blame the death and former divorce on the former non-custodial parent, and this may have an impact on the new bonding. They also found that a therapeutic relationship may help the child in the years after the custodial parent's death and through the transition process. ${ }^{[6]}$ Walls (1995b) showed different expressions of bereavement in adolescents who had experienced non-custodial parental death. Their reactions and feelings were related to the extent to which they had supportive parents who helped them through the bereavement, how they had experienced the divorce, and finally, to what extent they had experienced disenfranchised grief. Disenfranchised grievers are generally left unsupported and they are often denied the right to openly grieve, and even denied attendance at the funeral. As a consequence they may feel anger and lack of understanding, and sometimes self-anger. ${ }^{[34]}$ Gordon et al. show that problems and conflicts between the critically ill and dying custodial parent and the non-custodial parent can have a great impact on decision-making for the child's future. Multidisciplinary help from nurses and other professionals is needed in order to make good, legal, rational decisions for the child. It is also important that the custodial parent is still able to be involved in that process. Gordon et al. also show that, although the non-custodial parent may have been absent, children still want a relationship with that parent. ${ }^{[30]}$ Walls (1995a) found that when the grief is due to the loss of the non-custodial father, as opposed to the father in an intact family, there is less expectation that those around the child will display grief responses, symptoms, support, and expressions of sympathy. Thus, the loss of a non-custodial father is likely to result in a disenfranchised grief. However, this tendency can be counteracted by a supportive mother. ${ }^{[33]}$

Seven studies had lower relevance, either because their aim was not solely about children's loss and double bereavement, or because the focus was mainly on family support programmes. Nevertheless, all the studies had findings that were somewhat relevant to the issue of double bereavement. Four of the studies showed considerable consequences for mental health, e.g., severe mood disorders, ${ }^{[32]}$ psychosis, ${ }^{[27]}$ current or lifetime depressions ${ }^{[28]}$ and PTSD. ${ }^{[29]}$ Davey showed that adolescents in divorced families with parental critical illness try to protect their parents by not sharing their feelings. They feel overwhelmed by sadness and fear, which the parents are often unaware of. ${ }^{[31]}$ Grossman highlighted that family support programmes, supportive and nurturing mothers, and no exposure to parents who are mentally ill, may help children to handle the double loss and bereavement better and reduce the risk of developing psychological problems. ${ }^{\text {[29] }}$ Other studies, such as Bugge (2009), confirmed that when one of the parents is critically ill in divorced families, the parents' conflicts are reduced when they attend family support programmes, and that professionals may act as buffers between the ex-partners, and between the critically ill parent and the child. ${ }^{[26]}$ Children need to be in dialogue with other family members, but Bugge showed that the children also need support, without having to think about family members' reactions. ${ }^{[25]}$

The data analysis and reduction from the review revealed a number of themes and subcategories across the included studies, as depicted in Table 3. 
Table 3. Themes and subcategories

\begin{tabular}{ll}
\hline Themes & Subcategories \\
\hline & Age \\
Complexity in children's and adolescents' experiences of double bereavement & Gender \\
& Feelings \\
Challenges related to custodial or a non-custodial parental loss & Multiple losses \\
& Custodial loss \\
Increased risk of mental health problems & Non-custodial loss \\
Support and interventions is crucial & Severe mood disorders \\
& Psychosis \\
& Depression \\
& PTSD \\
\hline
\end{tabular}

\section{Discussion}

\subsection{Complexity in children's and adolescents' experi- ences of double bereavement}

Children and adolescents with divorced parents describe a range of challenges involved in their double loss and bereavement. ${ }^{[25]}$ Parental divorce followed by critical illness/death represents loss upon loss. ${ }^{[2,27,35,36]}$ Children and adolescents are faced with the challenge of managing the double bereavement, which involves being able to shift between the loss and a restoration orientation. ${ }^{[2,35]} \mathrm{Kim}$ et al. found, in a review of bereavement needs, that unrelieved pain and anxiety in the patient and family before death are related to several postdeath psychological and physical morbidities in survivors. ${ }^{[11]}$ Also, the individual's age, gender, pre-losses and losses following life changes, as well as the help the family receive, are important. ${ }^{[11,25]}$ Regarding age, adolescents in divorced families try to protect their parents and do not share their feelings openly with them. The oldest adolescents in the family tend to become caretakers, helping their parents or siblings in practical matters, and parents are often unaware of the stress and overwhelming feelings of sadness and fear in their adolescent. ${ }^{[31]}$ Children can be preoccupied by thoughts of who will take care of them, and also experience loneliness and depression as adolescents do. ${ }^{[32]}$ They also have difficulties with understanding their own feelings and reactions, and relate these to the parent's illness and death. Thoughts of death are prevalent among both younger and older children. ${ }^{[25]}$ Moreover, boys tend to turn inward when they are worried and anxious by using distraction or avoidance, or they have limited access to their feelings. ${ }^{[5,31]}$ Girls tend to talk more openly about their worries or fears. ${ }^{[31]}$ Girls, who have lost a non-custodial father and have a supportive mother, express the usual grief reactions, such as shock, numbness, disbelief, intense mourning and period of adjustment. When the children or adolescents are left unsupported, more disenfranchised grief is typically seen. ${ }^{[5]}$ Very few attend the funeral. Yet, people around them expect them to mourn. ${ }^{[5]}$ Furthermore, when the doubly bereaved child or adolescent moves to a new home after the death of a custodial parent, he or she must adapt to a new family culture and dynamic and a new local community. Besides having lost a custodial parent, they also lose their home. This loss may symbolize the attachment to the deceased parent and any other relatives, and perhaps also to the lifestyle the child used to have. ${ }^{[6,32]}$ If the new custodial parent or any step-parent is not mourning, the child may experience a lack of acknowledgment or understanding of its own feelings, which may cause a disenfranchised grief reaction. ${ }^{[6,33]}$

\subsection{Challenges related to custodial or non-custodial parental loss}

When parents are divorced and either the custodial or noncustodial parent develop a critical illness with expected death or death, children and adolescents may experience increased risk for developing psychosocial problems, and sometimes also conflicts between parents regarding custodial or living arrangements. ${ }^{[25]}$ However, the challenges are different, depending on whether it is the custodial or the non-custodial parent that might die or is dead. ${ }^{[6]}$

When the custodial parent dies, the child may already have fears of commitment as a consequence of the divorce and may be vulnerable in relationships. ${ }^{[32]}$ If a critically ill custodial 
parent avoids addressing possible living arrangements for the children's future, subsequent transitions may be impeded. ${ }^{[6]}$ This may be particularly challenging if the non-custodial parent has been uninvolved or absent, and the critically ill custodial parent opposes a change in custody to the surviving parent. If he or she insists on taking over custody when the other parent dies, this may cause a custody conflict between the parents, which perhaps would not have developed without the likely or impending death of the custodial parent.

Children and adolescents whose parents are divorced and subsequently experience custodial parental death may have worries about relocation to the non-custodial parent. If the non-custodial parent has been unknown to the child, the death of the custodial parent may also result in a search for the biological parent. ${ }^{[6,30]}$ Sometimes, children and adolescents can blame their non-custodial parent for the stress of the divorce and subsequently for the death of their custodial parent. Moreover, if the non-custodial parent becomes the new custodial parent, he or she may not be as distressed as the child or adolescent about the death of their ex-partner and may not fully understand the offspring's bereavement. ${ }^{[6]}$

When the loss of a non-custodial parent occurs, there will be other challenges concerning the bereavement than when the custodial parent dies. Lack of understanding seems to be a more common response when the loss is of a non-custodial parent. This may result in a disenfranchised grief reaction, with loss of personal meaning in the loss, leaving the child or adolescent alone in silence. The anger then differs from normal grief reactions and is shown as anger toward lack of understanding. ${ }^{[33,34]}$ The surviving custodial parent plays an important role, particularly when it comes to helping the child or adolescent to cope with the loss and bereavement in a way that promotes mental health. ${ }^{[33,34]}$

\subsection{Increased risk of mental health problems}

The experience of double loss and bereavement may have a great impact on children's and adolescents' mental health. When this occurs before the age of 16 , there is more than double the risk of developing psychosis. ${ }^{[27]}$ When it occurs before the age of 15 , there is three to four times higher risk in women for current or lifetime depression, compared to individuals who have experienced only one of the losses. ${ }^{[28]}$ Also, PTSD is significantly related to double bereavement, particularly if the death is caused by paternal suicide. ${ }^{[29]} \mathrm{Lu}$ et al. found that, among children with severe mood disorders, it was also related to risk of adverse childhood events, such as divorce and parental death. ${ }^{[32]}$ The children and adolescents who struggle with double bereavement often express problems related to mental health issues, such as stress, loneliness, anxiety and depression and they have a risk of developing in an unhealthy way if left alone without psychosocial support. ${ }^{[28,36,37]}$

\subsection{Support and interventions is crucial}

Doubly bereaved children and adolescents who are left with lack of support are particularly at risk of developing psychological problems. Participating in support groups, getting help from multidisciplinary team or a therapist may compensate for any shortages of parental support and acknowledgment of the bereavement. ${ }^{[25,33,38]}$ Also, the surviving parents may need support in order to facilitate their children's coping. And by gaining insight into their children's reactions, such as anger and rejection, the parents may be able to cope better with these reactions, and thus improve their relationship with the child or adolescent. ${ }^{[26]}$ Moreover, the professionals may act as a buffer between the partner and ex-partner and child. ${ }^{[6,26]}$ A golden opportunity for intervention may be the period between a possible deadly diagnosis and any forthcoming death, where the clinicians may help the family members to talk about and prepare for the profound changes that might occur. ${ }^{[6]}$ This could include encouraging the children and adolescents to use their strengths and receive help in order to retain positive memories of the critically ill parent, as this can prevent complicated grief. ${ }^{[6,31]}$ Support programmes need to take into account the special circumstances of children and adolescents of separated or divorced parents in the support they offer. ${ }^{[25]}$ Nurses highlight that when they have patients involved in a custodial case, the hospital should make family group sessions available and be able to provide help in any difficult decision-making related to the custody issues. ${ }^{[38]}$ The young people need to know that they will be taken care of and they need the support of all the loving adults involved. ${ }^{[11,30,39]}$ Single mothers often get help through support groups or other patients or friends, whereas single fathers are more reluctant to receive help, or they have fewer confidants from whom they can seek support. ${ }^{[26,31]}$ Most of the adolescents talk with friends, but some do not want to involve the school, either because they are afraid of being teased or because they don't want attention. However, for most children and adolescents, school is a resource. ${ }^{[31]}$ Moreover, the review clearly indicates that nurses and other professionals working with critically ill patients need insight and knowledge about double bereavement issues, because their support may be crucial to the children, adolescents and their families. ${ }^{[11,25,31]}$

\subsection{Methodological issues and limitations}

Although the data search was conducted according to scientific procedures, ensuring replicability and transparency, there are some limitations to take into consideration. ${ }^{[1,40,41]}$ Only a few of the articles focused specifically on nursing, 
even though most of the research addressed various health issues. Thus, the review does not, to any great extent, inform nursing practice explicitly. Moreover, the integration of qualitative and quantitative research brings challenges, since these research approaches are based on somewhat different epistemologies and scientifically traditions. ${ }^{[41]}$ More specifically, the categorization of very different studies into high and low quality and relevance could obviously be questioned, particularly since it was not based on objective criteria, but on a general evaluation in the context of the current study. However, all the authors participated in the categorization and consensus was obtained for all articles. The analyses were otherwise carried out according to principles of systematic integrative review, outlined by Whittemore and Knafl. ${ }^{[1]}$

\section{CONClusion AND TOPICS FOR FUTURE RESEARCH}

Even though a substantial proportion of children and adolescents who experience parental death or critical illness with imminent death have also previously experienced parental divorce, surprisingly few studies have investigated this double bereavement. The current review study indicates that these children and adolescents may be a vulnerable group and that we need more information about them. We would particularly suggest more information about what characterize these children and adolescents and to what extent they may need more or other types of support than other bereaved children and adolescents. If any special needs are identified support measures targeting these children and adolescents should be developed and evaluated. Such measures might include both nursing practice and multidisciplinary practice.

The lack of studies on double bereavement may perhaps reflect the fact that bereavement research and divorce research traditionally have been two separate research fields without much interchange. This is notable since both research fields focus on profound losses within family relationships. A corresponding separation also seems to exist when it comes to support measures aiming at individuals experiencing any of these losses. Thus, future research on double bereavement as well as development of any support measures aiming at doubly bereaved children and adolescents may imply more cooperation between experts of bereavement and divorce, respectively. This way the research and clinical practice focusing on double bereavement could contribute to dismantle the inapt barriers between the fields of bereavement and divorce, and therefore represent a valuable bridge between these fields.

\section{Conflicts of InTEREST Disclosure}

The authors declare no competing interest.

\section{REFERENCES}

[1] Whittemore R, Knafl K. The integrative review: Updated methodology. J Adv Nurs. 2005; 52(5): 546-553. PMID:16268861. http: //dx.doi.org/10.1111/j.1365-2648.2005.03621.x

[2] Stroebe M, Schut H. The dual process model of coping with bereavement: Rationale and description. Death Stud. 1999; 23(3): 197-224. PMID:10848151. http://dx.doi .org/10.1080/07481189920 1046

[3] European Commission E. Divorces by country of birth of wife and husband (partner). 2013.

[4] Frølander A. Børn med død forælder. Danmarks Statistik. 2015.

[5] Walls MJ. Disenfranchised grief: The death of a noncustodial parent. [Doctor of Psychology]. Indiana University of Pennsylvania; 1995.

[6] Werner-Lin A, Biank N, Rubenstein B. There's no place like home: Preparing children for geographical and relational attachment disruptions following parental death to cancer. Clinical Social Work Journal. 2010; 38(1): 132-143. http://dx.doi.org/10.1007/s 10615-009-0233-1

[7] Krattenmacher T, Kühne F, Ernst J, et al. Parental cancer: Factors associated with children's psychosocial adjustment - a systematic review. J Psychosom Res. 2012; 72(5): 344-356. PMID:22469276. http://dx.doi.org/10.1016/j.jpsychores.2012.01.011

[8] WHO. The world health report, mental health: New understanding, new hope. 2001.

[9] Amato PR, Anthony CJ. Estimating the effects of parental divorce and death with fixed effects models. J Marriage Fam. 2014; 76(2): 370-386. http://dx.doi.org/10.1111/jomf . 12100
[10] Amato PR. Children of divorce in the 1990s: An update of the amato and keith (1991) meta-analysis. Journal of Family Psychology. 2001; 15(3): 355-370. PMID:11584788. http://dx.doi.org/10.1037 10893-3200.15.3.355

[11] Kim Y, Lucette A, Loscalzo M. Bereavement needs of adults, children, and families after cancer. Cancer J. 2013; 19(5): 444-457. PMID:24051619. http://dx.doi.org/10.1097/PPO.0b013e3 182a5babe

[12] Amato PR, Keith B. Parental divorce and the well-being of children: A meta-analysis. Psychol Bull. 1991; 110(1): 26-46. http: //dx.doi.org/10.1037/0033-2909.110.1.26

[13] Amato PR, Keith B. Parental divorce and adult well-being: A metaanalysis. Journal of Marriage and the Family. 1991; 53(1): 43-58. http://dx.doi.org/10.2307/353132

[14] Størksen I, Røysamb E, Holmen TL, et al. Adolescent adjustment and well-being: Effects of parental divorce and distress. Scand J Psychol. 2006; 47(1): 75-84. PMID:16433664. http://dx.doi.o $\mathrm{rg} / 10.1111 / \mathrm{j} .1467-9450.2006 .00494 . \mathrm{x}$

[15] Størksen I, Røysamb E, Moum T, et al. Adolescents with a childhood experience of parental divorce: A longitudinal study of mental health and adjustment. J Adolesc. 2005; 28(6): 725-739. PMID:16291507. http://dx.doi.org/10.1016/j.adolescen ce.2005.01.001

[16] Wallerstein JS. Children after divorce: Wounds that don't heal. Perspect Psychiatr Care. 1987; 24(3-4): 107-113. PMID:3508962. http: //dx.doi.org/10.1111/j.1744-6163.1987.tb00291.x 
[17] Ottosen M, Andersen D, Nielsen L, et al. Børn og unge i danmark: Velfærd og trivsel; 2010.

[18] Rodgers B, Power C, Hope S. Parental divorce and adult psychological distress: Evidence from a national cohort: A research note. Child Psychology \& Psychiatry \& Allied Disciplines. 1997; 38(7): 867-872. http://dx.doi.org/10.1111/j.1469-7610. 1997.tb01605.x

[19] Amato P. Long-term implications of parental divorce for adult selfconcept. 1988; 9: 201-13.

[20] McLanahan S, Sandefur G. Growing up with a single parent. what hurts, what helps. 1994.

[21] McLeod JD. Childhood parental loss and adult depression. Journal of Health and Social Behavior. 1991; 32: 205-220. PMID:1940206. http://dx.doi.org/10.2307/2136804

[22] Mack KY. Childhood family disruptions and adult well-being: The differential effects of divorce and parental death. Death Stud. 2001; 25(5): 419-443. PMID:11806412. http://dx.doi.org/10.1080 /074811801750257527

[23] Garrard J. Health sciences literature review made easy: The matrix method. 4th ed. Burlington, MA: Jones \& Bartlett Learning; 2014. xii, $217 \mathrm{p}$.

[24] Miles M, Huberman A. Qualitative data analysis: An expanded sourcebook. 2nd ed. Thousand Oaks, Calif., London: Sage; 1994.

[25] Bugge KE, Helseth S, Darbyshire P. Children's experiences of participation in a family support program when their parent has incurable cancer. Cancer Nurs. 2008; 31(6): 426-434. PMID:18987509. http: //dx.doi.org/10.1097/01. NCC.0000339250.83571.b0

[26] Bugge KE, Helseth S, Darbyshire P. Parents' experiences of a family support program when a parent has incurable cancer. J Clin Nurs. 2009; 18(24): 3480-3488. PMID:19732243. http://dx.doi.org /10.1111/j.1365-2702.2009.02871.x

[27] Morgan C, Kirkbride J, Leff J, et al. Parental separation, loss and psychosis in different ethnic groups: A case-control study. Psychol Med. 2007; 37(4): 495-503. PMID:17094816. http://dx.doi.o rg/10.1017/S0033291706009330

[28] Oakley Browne MA, Joyce PR, Wells JE, et al. Disruptions in childhood parental care as risk factors for major depression in adult women. Aust N Z J Psychiatry. 1995; 29(3): 437-448. PMID:8573047. http://dx.doi.org/10.3109/00048679509064952

[29] Grossman JA, Clark DC, Gross D, et al. Child bereavement after paternal suicide. J Child Adolesc Psychiatr Nurs. 1995; 8(2): 5-17. PMID:7795955. http://dx.doi.org/10.1111/j.1744-6 171.1995.tb00525.x
[30] Gordon RB, Duttera MJ, Lee C, et al. Multidisciplinary rounds. A breast cancer patient involved in a child custody suit. Cancer Pract. 1999; 7(2): 55-58. PMID:10352061. http://dx.doi.org/10.10 46/j.1523-5394.1999.07201.x

[31] Davey MP, Askew J, Godette K. Parent and adolescent responses to non-terminal parental cancer: A retrospective multiple-case pilot study. FAM SYST HEALTH. 2003; 21(3): 245-258. http: //dx.doi.org/10.1037/1091-7527.21.3.245

[32] Lu W, Mueser KT, Rosenberg SD, et al. Correlates of adverse childhood experiences among adults with severe mood disorders. Psychiatr Serv. 2008; 59(9): 1018-1026. PMID:18757595. http: //dx.doi.org/10.1176/ps.2008.59.9.1018

[33] Walls MJ. Disenfranchised grief: The death of a noncustodial parent. [Doctor of Psychology]. Indiana University of Pennsylvania; 1995a.

[34] Walls MJ. Disenfranchised grief: The death of a noncustodial parent. [Doctor of Psychology]. Indiana University of Pennsylvania; 1995b.

[35] Stroebe M, Schut H. The dual process model of coping with bereavement: A decade on. Omega: Journal of Death \& Dying. 2010; 61(4): 273-289. http://dx.doi.org/10.2190/om.61.4.b

[36] Rosenberg SD, Lu W, Mueser KT, et al. Correlates of adverse childhood events among adults with schizophrenia spectrum disorders. Psychiatric Services. 2007; 58(2): 245-253. PMID:17287383. http://dx.doi.org/10.1176/ps.2007.58.2.245

[37] Davey MP, Askew J, Godette K. Parent and adolescent responses to non-terminal parental cancer: A retrospective multiple-case pilot study. FAM SYST HEALTH. 2003; 21(3): 245-258. http: //dx.doi.org/10.1037/1091-7527.21.3.245

[38] Gordon RB, Duttera MJ, Lee C, et al. Multidisciplinary rounds. A breast cancer patient involved in a child custody suit. Cancer Pract. 1999; 7(2): 55-58. PMID:10352061. http://dx.doi.org/10.10 46/j.1523-5394.1999.07201.x

[39] Buchwald D, Delmar C, Schantz-Laursen B. How children handle life when their mother or father is seriously ill and dying. Scand J Caring Sci. 2012; 26(2): 228-235. PMID:21950563. http: //dx.doi.org/10.1111/j.1471-6712.2011.00922.x

[40] Hayden JA, Côté P, Bombardier C. Evaluation of the quality of prognosis studies in systematic reviews. Ann Intern Med. 2006; 144(6): 427-W78. PMID:16549855. http://dx.doi.org/10.7326/000 3-4819-144-6-200603210-00010

[41] Greenhalgh T. How to read a paper: papers that summarize other papers systematic reviews and meta-analyses. BMJ. 1997; 315: 672. http://dx.doi.org/10.1136/bmj.315.7109.672 